\title{
Utility of selected tumor-associated antigens in systemic sclerosis-related interstitial lung disease - a retrospective single-center study
}

\section{Przydatność oznaczeń wybranych markerów nowotworowych w śródmiąższowej chorobie płuc w przebiegu twardziny układowej - retrospektywne badanie jednoośrodkowe}

\author{
Filip Fijołek', Barbara Pasierb', Agnieszka Gerkowicz², Dorota Krasowska² \\ 'Student's Scientific Association at the Department of Dermatology, Venereology and Paediatric Dermatology, Medical University \\ of Lublin, Poland \\ 2Department of Dermatology, Venereology and Paediatric Dermatology, Medical University of Lublin, Poland \\ 'Studenckie Koło Naukowe przy Katedrze i Klinice Dermatologii, Wenerologii i Dermatologii Dziecięcej, Uniwersytet Medyczny \\ w Lublinie, Polska \\ ${ }^{2}$ Katedra i Klinika Dermatologii, Wenerologii i Dermatologii Dziecięcej, Uniwersytet Medyczny w Lublinie, Polska
}

\section{CORRESPONDING AUTHOR/ ADRES DO KORESPONDENCJI: Filip Fijołek \\ Studenckie Koło Naukowe przy Katedrze i Klinice Dermatologii, Wenerologii i Dermatologii Dziecięcej Uniwersytet Medyczny ul. Staszica 11 20-081 Lublin tel.: +48660049798 e-mail: filip.fijolek@gmail.com}

\begin{abstract}
Introduction. Systemic sclerosis is a connective tissue disease, in which interstitial lung disease is one of the most common clinical manifestations, being the leading cause of death among this group of patients as well. Recent literature data suggest that selected tumor-associated antigens correlate with pulmonary involvement in systemic sclerosis. Therefore they may serve as a prognostic factor for presence of interstitial lung disease.

Objective. To evaluate the usefulness of assessing tumor-associated antigens in systemic sclerosis according to coexistence of interstitial lung disease.

Material and methods. We performed a retrospective analysis of data from medical records of 51 patients with systemic sclerosis in whom at least one tumor-associated antigen level was assessed. Clinical parameters, subtype of the disease and presence of interstitial lung disease were evaluated.

Results. There were 28 patients with interstitial lung disease and 23 patients without interstitial lung disease. Elevated levels of at least tumor-associated antigen were observed in 20 of 28 patients with interstitial lung disease and 7 of 23 patients without interstitial lung disease. Levels of CA 15-3 and CA 125 directly correlated with presence of systemic sclerosis-related interstitial lung disease $(p=0.046$ and $p=0.030$, respectively)

Conclusions. Elevated levels of selected tumor-associated antigens are observed in systemic sclerosis. Some of them correlate with presence of interstitial lung disease. Assessment of certain tumor-associated antigen levels among patients with systemic sclerosis is essential in early diagnosis of malignancies and monitoring the course of the disease.
\end{abstract}




\section{STRESZCZENIE}

Wprowadzenie. Twardzina układowa należy do chorób tkanki łącznej. Jedną z najczęstszych manifestacji klinicznych tego schorzenia, a jednocześnie główną przyczyną zgonów chorych na twardzinę układową jest śródmiąższowa choroba płuc. Według najnowszych danych $\mathrm{z}$ piśmiennictwa niektóre markery nowotworowe wykazują korelację $\mathrm{z}$ zajęciem płuc w przebiegu twardziny układowej i dlatego mogą służyć jako czynnik prognostyczny rozwoju śródmiąższowej choroby płuc u pacjentów $z$ tym schorzeniem.

Cel. Ocena przydatności oznaczania markerów nowotworowych u pacjentów z twardziną układową pod kątem współwystępowania śródmiąższowej choroby płuc.

Materiał i metody. Przeprowadzono retrospektywną analizę danych uzyskanych z dokumentacji medycznej 51 pacjentów z twardziną układową, u których oznaczono co najmniej jeden marker nowotworowy. W ocenie uwzględniono parametry kliniczne, podtyp choroby oraz obecność śródmiąższowej choroby płuc.

Wyniki. Grupa badana obejmowała 28 pacjentów ze śródmiąższową chorobą płuc i 23 pacjentów bez śródmiąższowej choroby płuc. Podwyższone stężenie co najmniej jednego markera nowotworowego stwierdzono u 20 spośród 28 pacjentów ze śródmiąższową chorobą płuc i u 7 spośród 23 pacjentów bez tego schorzenia. Stwierdzono bezpośrednią korelację między stężeniem CA 15-3 i CA 125 a obecnością śródmiąższowej choroby płuc w przebiegu twardziny układowej (odpowiednio $p=0,046$ i $p=0,030)$.

Wnioski. U pacjentów z twardziną układową występuje zwiększone stężenie pewnych markerów nowotworowych. Niektóre $z$ nich są związane z obecnością śródmiąższowej choroby płuc. Oznaczanie stężenia niektórych markerów nowotworowych u pacjentów $\mathrm{z}$ twardziną układową ma kluczowe znaczenie we wczesnej diagnostyce nowotworów i monitorowaniu przebiegu choroby.

Key words: systemic sclerosis, interstitial lung disease, tumor-associated antigens.

Słowa kluczowe: twardzina układowa, śródmiąższowa choroba płuc, markery nowotworowe.

\section{INTRODUCTION}

Systemic sclerosis (SSc) is an autoimmune connective tissue disease characterized by vascular alterations, immune-mediated fibrosis of the skin and internal organs, as well as production of autoantibodies [1, 2]. There are two main forms of SSc: limited SSc (1SSc) and diffuse SSc (dSSc) [3, 4].

One of the most common clinical manifestations of SSc is lung involvement, presenting as interstitial lung disease (ILD) and/or pulmonary arterial hypertension $[5,6]$. The pathogenesis of ILD in the course of SSc is not completely understood, but immunemediated fibrosis plays a crucial role [5]. Its diagnosis is based on chest high-resolution computed tomography (HRCT), pulmonary function tests (PFTs),

\section{WPROWADZENIE}

Twardzina układowa (systemic sclerosis - SSc) jest autoimmunologiczną chorobą tkanki łącznej, która charakteryzuje się występowaniem zmian naczyniowych, zwłóknieniem skóry i narządów wewnętrznych oraz wytwarzaniem autoprzeciwciał [1, 2]. Wyróżnia się dwie główne postaci SSc: twardzina układowa ograniczona (limited systemic sclerosis 1SSc) oraz twardzina układowa uogólniona (diffuse systemic sclerosis - dSSc) $[3,4]$.

Jednym z najczęstszych objawów w obrazie klinicznym SSc jest zajęcie płuc w postaci śródmiąższowej choroby płuc (interstitial lung disease - ILD) i/lub tętniczego nadciśnienia płucnego [5, 6]. Patogeneza ILD w przebiegu SSc nie jest do końca poznana, jed- 
including forced vital capacity (FVC) and total lung capacity (TLC), as well as diffusion lung capacity for carbon monoxide (DLCO) [7]. Major risk factors of developing ILD in the course of SSc are male sex, diffuse subtype of the disease, older age at the disease onset, short time of the disease duration and presence of anti-Scl-70 antibodies [8, 9]. ILD is still one of the main causes of morbidity and mortality in patients with SSc, so its appropriate diagnosis and therapy are required to stop the disease progression and improve the quality of patients' lives [10].

Potential biomarkers of SSc-related interstitial lung disease (SSc-ILD) have been evaluated in various studies. One of the most widely studied particles is Krebs von den Lungen-6 (KL-6) [11-26]. It is a glycoprotein, a product of the MUC1 gene, whose expression is found on epithelial cells, especially on type II pneumocytes and bronchial epithelial cells. KL-6 has a profibrotic and antiapoptotic effect on pulmonary fibroblasts. Its increase in serum concentrations is observed after cells' damage and during their regeneration in a variety of pathological conditions, including SSc-ILD [27, 28].

Recent data show that certain tumor-associated antigens may be used as biomarkers of ILD-SSc [2935].

\section{OBJECTIVE}

The aim of the study was to evaluate the usefulness of assessing tumor-associated antigens in SSC according to coexistence of ILD.

\section{MATERIAL AND METHODS}

Retrospective analysis of data from medical records of 51 patients with SSc from 2005 to 2017 was performed. There were 51 females (100\%) aged 37-88 (median age: 66). We included in the assessment medical records of patients who had at least one tumorassociated antigen serum level evaluated, including CA 125 (carbohydrate antigen 125), HE4 (human epididymis protein 4), CA 19-9 (carbohydrate antigen 19-9), CEA (carcinoembryonic antigen), CA 15-3 (carbohydrate antigen 15-3), AFP (a-fetoprotein) and CA 72-4 (carbohydrate antigen 72-4). In all cases antigen levels were assessed to monitor the immunosuppressive therapy and to exclude malignant processes. Appropriate diagnostic tests and specialist consultations were performed in all patients with abnormal levels of tumor-associated antigens in order to exclude malignancies or other conditions which may result in an increase of studied antigens' levels. Chest radiograph and abdominal ultrasonography were performed in all cases. Gynecologic ultrasonogra- nak kluczową rolę odgrywa w niej włóknienie o podłożu immunologicznym [5]. Rozpoznanie opiera się na wynikach badania klatki piersiowej metodą tomografii komputerowej o wysokiej rozdzielczości (high-resolution computed tomography - HRCT), testach czynnościowych płuc (pulmonary function tests - PFT), m.in. natężonej pojemności życiowej (forced vital capacity - FVC) i całkowitej pojemności płuc (total lung capacity - TLC), a także pomiarach zdolności dyfuzyjnej płuc dla tlenku węgla (diffusion lung capacity for carbon monoxide - DLCO) [7]. Do głównych czynników ryzyka rozwoju ILD w przebiegu SSc należy zaliczyć: płeć męską, uogólniony podtyp choroby, początek w podeszłym wieku, krótki czas trwania choroby oraz obecność przeciwciał anty-Scl-70 $[8,9]$. ILD nadal jest jedną z głównych przyczyn zachorowalności i śmiertelności chorych na SSc. Z tego względu prawidłowe rozpoznanie i leczenie są niezbędne, aby zahamować progresję choroby i osiągnąć poprawę jakości życia chorych [10].

Potencjalne biomarkery ILD w przebiegu SSc (SSc-related interstitial lung disease - SSc-ILD) były analizowane $\mathrm{w}$ wielu badaniach. Jedną z najczęściej badanych cząsteczek jest marker KL-6 (Krebs von den Lungen-6) [11-26]. Jest to glikoproteina produkowana przez gen MUC1, która ulega ekspresji na komórkach nabłonka, zwłaszcza pneumocytach typu II i komórkach nabłonka oskrzelików oddechowych. KL-6 ma działanie profibrotyczne i przeciwapoptotyczne na fibroblasty płucne. Wzrost stężeń KL-6 w surowicy stwierdza się po uszkodzeniu komórek i podczas procesu ich regeneracji w przebiegu różnych stanów patologicznych, takich jak SSc-ILD [27, 28].

Najnowsze dane pokazują, że niektóre markery nowotworowe mogą być wykorzystywane jako biomarkery SSc-ILD [29-35].

\section{CEL}

Celem pracy była ocena przydatności oznaczania markerów nowotworowych u pacjentów z SSc pod kątem współwystępowania ILD.

\section{MATERIAŁ I METODY}

Przeprowadzono retrospektywną analizę dokumentacji medycznej 51 pacjentów z SSc obejmującej lata 2005-2017. Grupę badaną stanowiło 51 kobiet (100\%) w wieku 37-88 lat (mediana wieku: 66 lat). Do analizy włączono dokumentację medyczną pacjentek, u których oznaczono stężenie co najmniej jednego markera nowotworowego w surowicy, m.in. CA 125 (markera węglowodanowego 125), HE4 (podfrakcji 4 ludzkiego białka z komórek nabłonkowych najądrza), CA 19-9 (markera węglowodanowego 19-9), CEA (markera rakowo-płodowego), CA 15-3 (markera wę- 
phy, cervical cytology and breast ultrasound or mammography were carried out in patients with increased levels of CA 125, CA 15-3 and HE4. Gastroscopy, colonoscopy and fecal occult blood test were additionally performed in patients with increased levels of antigens, which may indicate alimentary tract involvement. FibroScan was performed in 2 patients in order to exclude liver fibrosis. Upper cut-off levels of studied antigens were used in accordance to those suggested by the laboratory. Clinical parameters, subtype of the disease and presence of ILD (diagnosed based on chest HRCT results) were retrospectively evaluated.

The study was conducted in accordance with The Declaration of Helsinki and Good Clinical Practice.

\section{Statistical analysis}

Statistical analysis was performed with Statistica software. The $\mathrm{x}^{2}$ test of Independence was used, considering a $p$-value less than 0.05 as statistically significant.

\section{RESULTS}

In the study group there were both patients with 1SSc ( 43 of $51-84.31 \%$ ) and those with dSSc (8 of $51-15.69 \%$ ). Twenty-eight of 51 patients were diagnosed with SSc-ILD and 23 of 51 patients were without SSc-ILD. CA 125, CA 15-3 and CEA were the most frequently assessed tumorassociated antigens in this group of patients - evaluated in $48(94.12 \%)$ patients. CA 19-9, AFP, HE4 and CA 72-4 were assessed in 47 (92.16\%), 38 (74.51\%), 29 (56.86\%) and $10(19.61 \%)$ patients, respectively (table 1). Twenty-seven patients $(52.94 \%)$ had increased levels of at least one tumor-associated antigen - $21(77.78 \%)$ patients with $1 S S c$ and $6(22.22 \%)$ patients with dSSc. Increased levels of at least one tumor-associated antigen were observed in 20 of 28 patients with ILD and 7 of 23 patients without ILD.

Levels of CA 15-3 and CA 125 directly correlated with presence of SSc-ILD $(p=0.046$ and $p=0.030$, respectively) (tables 2, 3). No correlations between other tumor-associated antigens and presence of SSc-ILD in the studied group were found. No malignancies were diagnosed in the studied group. Benign processes were diagnosed in 3 patients, including uterine myomas, ovarian fibroma and duodenal adenoma.

\section{DISCUSSION}

SSc-ILD is still a leading cause of mortality in this group of patients and it requires early diagnosis and appropriate treatment [10]. HRCT of the chest and PFTs are invaluable in the diagnostic process [7]. However, HRCT is associated with exposure to ionizing radiation, which is unfortunately the major glowodanowego 15-3), AFP (a-fetoproteiny) i CA 72-4 (markera węglowodanowego 72-4). We wszystkich przypadkach oznaczenia stężeń markerów wykonywano, aby monitorować terapię immunosupresyjną i wykluczyć złośliwe procesy nowotworowe. U wszystkich pacjentek z nieprawidłowymi stężeniami markerów nowotworowych wykonano odpowiednie badania diagnostyczne i przeprowadzono specjalistyczne konsultacje, aby wykluczyć nowotwory lub inne schorzenia, które mogą skutkować wzrostem stężenia badanych markerów. We wszystkich przypadkach wykonano badanie rentgenograficzne klatki piersiowej i ultrasonograficzne (USG) jamy brzusznej. U pacjentek z podwyższonym stężeniem CA 125, CA 15-3 i HE4 wykonano badanie USG ginekologiczne, badanie cytologiczne szyjki macicy oraz USG lub mammografię piersi. Dodatkowo u pacjentek, u których stężenie antygenów było podwyższone, przeprowadzono gastroskopię, kolonoskopię i badanie na obecność krwi utajonej w kale ze względu na możliwość zajęcia przewodu pokarmowego. U 2 pacjentek wykonano badanie elastograficzne wątroby (FibroScan), aby wykluczyć jej włóknienie. Przyjęto górne wartości graniczne badanych markerów zgodnie z wytycznymi laboratorium. Retrospektywnej ocenie poddano parametry kliniczne, podtyp choroby oraz obecność ILD (rozpoznanej na podstawie wyników badania HRCT klatki piersiowej).

Badanie zostało przeprowadzone zgodnie z zasadami etycznymi określonymi w Deklaracji helsińskiej i Zasadami dobrej praktyki klinicznej.

\section{Analiza statystyczna}

Analizę statystyczną przeprowadzono za pomocą programu Statistica. Zastosowano test niezależności $\mathrm{x}^{2}$. Za statystycznie istotne uznano wartości $p<0,05$.

\section{WYNIKI}

Badana grupa obejmowała pacjentki z 1SSc (43/51 $84,31 \%)$ i dSSc $(8 / 51-15,69 \%)$. U 28 spośród 51 pacjentek rozpoznano SSc-ILD, a u 23 nie stwierdzono SSc-ILD. Najczęściej oznaczanymi markerami w badanej grupie były CA 125, CA 15-3 i CEA - ich stężenie analizowano u 48 (94,12\%) chorych. Oznaczenia CA 19-9, AFP, HE4 i CA 72-4 wykonano odpowiednio u 47 (92,16\%), 38 (74,51\%), 29 (56,86\%) i 10 (19,61\%) pacjentek (tab. 1). U 27 (52,94\%) pacjentek - 21 (77,78\%) z 1SSc i $6(22,22 \%)$ z dSSc - stwierdzono podwyższone stężenie co najmniej jednego markera nowotworowego. Zwiększone stężenie co najmniej jednego markera nowotworowego występowało u 20 spośród 28 pacjentek z rozpoznaną ILD i u 7 spośród 23 pacjentek bez ILD.

Potwierdzono bezpośrednią korelację pomiędzy stężeniem CA 15-3 i CA 125 a obecnością SSc-ILD (odpowiednio $p=0,046$ i $p=0,030$ ) (tab. 2,3). Nie stwierdzono 
limitation of this method and, additionally, its utility in diagnosis of very early stages of ILD is strictly limited because some abnormalities may be unnoticed. Additionally, the early stages of SSc-ILD may be asymptomatic or associated with non-specific symptoms, seen in a variety of respiratory system conditions, such as cough and dyspnea $[8,9]$. Thus, serum biomarkers may be a helpful implement in early identification of SSc patients at risk of developing ILD. Potential utility of tumor-associated antigens in SSc-ILD is based on the fact that their expression is observed on cancer cells as well as on inflammatory cells. Their increased levels are associated above all with various types of malignancies. Due to their low sensitivity, specificity and predictive value to confirm or exclude the diagnosis, other tests are performed. Concentrations of their soluble forms can be assessed in the sera of patients and their measurement can be repeated if necessary [27, 28, 30, 34].

The exact role of tumor-associated antigens in autoimmune disease is not clear. Some of them (CEA, CA 19-9, CA 125 and CA 15-3) may serve as cell adhesion molecules (CAMs). Their molecular structure consists of carbohydrate motifs which bind to E-selecting, leading to endothelium activation during inflammatory processes underlying various pathological conditions, including SSc [30, 34]. Increase in serum concentrations of pulmonary-derived particles in the course of inflammation, including the one underlying SSc, is a result of different mechanisms: increased production due to the inflammation, decreased degradation and permeability in the alveolocapillary barrier leading to increased leakage to systemic blood circulation [27]. CA 15-3 is a product of the same gene that is responsible for KL-6 secretion; therefore it could be used in clinical prac- zależności między innymi markerami nowotworowymi i występowaniem SSc-ILD w badanej grupie. U badanych pacjentek nie rozpoznano nowotworów złośliwych. U 3 kobiet stwierdzono łagodne guzy, takie jak mięśniaki macicy, włókniak jajnika i gruczolak dwunastnicy.

\section{OMÓWIENIE}

SSc-ILD nadal jest główną przyczyną śmiertelności w omawianej grupie chorych i z tego względu wymaga wczesnego rozpoznania i wdrożenia odpowiedniego leczenia [10]. Badania HRCT klatki piersiowej oraz PFT odgrywają istotną rolę $\mathrm{w}$ procesie diagnostycznym [7]. Należy jednak podkreślić, że HRCT wiąże się $\mathrm{z}$ narażeniem pacjenta na promieniowanie jonizujące, co stanowi najbardziej istotne ograniczenie tej metody. Ściśle ograniczona jest także przydatność HRCT w diagnostyce bardzo wczesnych stadiów ILD, ponieważ niektóre nieprawidłowości mogą być w trakcie badania niezauważone. Oprócz tego we wczesnych stadiach SSc-ILD może przebiegać bezobjawowo lub z nieswoistymi objawami (kaszel, duszność), obserwowanymi w różnych schorzeniach układu oddechowego [8, 9]. Z tego względu oznaczenie biomarkerów w surowicy może być pomocne we wczesnej identyfikacji pacjentów z SSc, u których występuje ryzyko rozwoju ILD. Potencjalna przydatność oznaczeń markerów nowotworowych w SSc-ILD jest związana z faktem, że ich ekspresję obserwuje się zarówno na komórkach nowotworowych, jak i na komórkach zapalnych. Podwyższone stężenie markerów nowotworowych wiąże się przede wszystkim z różnymi typami nowotworów złośliwych. Ze względu na niską czułość, swoistość i wartość predykcyjną tego oznaczenia w zakresie potwierdzania lub wykluczania rozpoznania wykonywane są inne bada-

Table I. Tumor-associated antigens levels in patients with systemic sclerosis

Tabela I. Stężenia markerów nowotworowych u pacjentek z twardziną układową

\begin{tabular}{|c|c|c|c|c|c|c|c|}
\hline $\begin{array}{l}\text { Levels in serum/ } \\
\text { Stężenie w surowicy }\end{array}$ & CA 125 & HE4 & CA $19-9$ & CEA & CA I5-3 & AFP & CA $72-4$ \\
\hline $\begin{array}{l}\text { Reference range/ } \\
\text { Zakres referencyjny }\end{array}$ & $\begin{array}{c}0-35.00 \\
\mathrm{U} / \mathrm{ml}\end{array}$ & $\begin{array}{l}0-65.00 \\
\mathrm{pmol} / \mathrm{l}\end{array}$ & $\begin{array}{c}0-39.00 \\
\mathrm{U} / \mathrm{ml}\end{array}$ & $\begin{array}{c}0-6.50 \\
\mathrm{ng} / \mathrm{ml}\end{array}$ & $\begin{array}{c}0-30.00 \\
\mathrm{U} / \mathrm{ml}\end{array}$ & $\begin{array}{l}0-5.80 \\
\mathrm{IU} / \mathrm{ml}\end{array}$ & $\begin{array}{c}0-6.89 \\
\mathrm{ng} / \mathrm{ml}\end{array}$ \\
\hline $\begin{array}{l}\text { Patients' range (min.-max.)/ } \\
\text { Zakres u pacjentów (min.-maks.) }\end{array}$ & $\begin{array}{c}3.10-130.5 \\
\mathrm{U} / \mathrm{ml}\end{array}$ & $\begin{array}{c}\text { I.06-379.20 } \\
\mathrm{pmol} / \mathrm{l}\end{array}$ & $\begin{array}{c}0.60-150.30 \\
\mathrm{U} / \mathrm{ml}\end{array}$ & $\begin{array}{c}0.38-20.29 \\
\mathrm{ng} / \mathrm{ml}\end{array}$ & $\begin{array}{c}4.87-80.12 \\
\mathrm{U} / \mathrm{ml}\end{array}$ & $\begin{array}{c}0.90-27.70 \\
\mathrm{IU} / \mathrm{ml}\end{array}$ & $\begin{array}{c}0.83-17.00 \\
\mathrm{ng} / \mathrm{ml}\end{array}$ \\
\hline $\begin{array}{l}\text { Mean/median/ } \\
\text { Średnia/mediana }\end{array}$ & $\begin{array}{c}24.16 / \\
\mid 8.06 \mathrm{U} / \mathrm{ml}\end{array}$ & $\begin{array}{c}129.07 / \\
\text { I05.20 pmol// }\end{array}$ & $\begin{array}{l}12.57 / \\
6.15 \mathrm{U} / \mathrm{ml}\end{array}$ & $\begin{array}{c}3.01 / \\
1.99 \mathrm{ng} / \mathrm{ml}\end{array}$ & $\begin{array}{c}22.00 / \\
|8.8| \mathrm{U} / \mathrm{ml}\end{array}$ & $\begin{array}{c}3.56 / \\
2.35 \mathrm{IU} / \mathrm{ml}\end{array}$ & $\begin{array}{c}5.86 / \\
2.80 \mathrm{ng} / \mathrm{ml}\end{array}$ \\
\hline $\begin{array}{l}\text { Normal levels (\%)/ } \\
\text { Wartości prawidłowe (\%) }\end{array}$ & 81.3 & 27.6 & 91.5 & 95.8 & 81.3 & 92.1 & 70.0 \\
\hline $\begin{array}{l}>1 \times U L N />1 \times G G N \\
\leq 2 \times U L N / \leq 2 \times G G N\end{array}$ & 14.6 & 27.6 & 6.4 & 2.1 & 14.6 & 2.6 & 10.0 \\
\hline $\begin{array}{l}>2 \times U L N />2 \times G G N \\
\leq 3 \times U L N / \leq 3 \times G G N\end{array}$ & 2.1 & 24.1 & 0.0 & 0.0 & 4.2 & 2.6 & 20.0 \\
\hline $\begin{array}{l}>3 \times U L N />3 \times G G N \\
\leq 4 \times U L N / \leq 4 \times G G N\end{array}$ & 2.1 & 13.8 & 2.1 & 2.1 & 0.0 & 0.0 & 0.0 \\
\hline$>4 \times U L N />4 \times G G N$ & 0.0 & 6.9 & 0.0 & 0.0 & 0.0 & 2.6 & 0.0 \\
\hline
\end{tabular}

ULN - upper limit norm, GGN - górna granica normy. 
Table 2. CA I 25 levels in patients with systemic sclerosis with or without interstitial lung disease

Tabela 2. Stężenia CA 125 u pacjentek z twardziną układową ze śródmiąższową chorobą płuc lub bez niej

\begin{tabular}{|c|c|c|c|c|}
\hline \multirow[t]{2}{*}{ CA 125} & \multicolumn{2}{|c|}{$\begin{array}{c}\text { Interstitial } \\
\text { lung disease/ } \\
\text { Śródmiąższowa } \\
\text { choroba płuc }\end{array}$} & \multirow[t]{2}{*}{$\begin{array}{c}\text { Total/ } \\
\text { Łącznie }\end{array}$} & \multirow[t]{2}{*}{$\begin{array}{l}\text { Value of } p / \\
\text { Wartość } p\end{array}$} \\
\hline & $\begin{array}{c}\text { Absent/ } \\
\text { Nieobecna }\end{array}$ & $\begin{array}{l}\text { Present/ } \\
\text { Obecna }\end{array}$ & & \\
\hline \multirow{2}{*}{$\begin{array}{l}\text { Normal levels/ } \\
\text { Wartości } \\
\text { prawidłowe }\end{array}$} & 21 & 18 & 39 & \\
\hline & $95.5 \%$ & $69.2 \%$ & $81.3 \%$ & \\
\hline \multirow{2}{*}{$\begin{array}{l}>1 \times \text { ULN/ } \\
>1 \times G G N \\
\leq 2 \times U L N / \\
\leq 2 \times G G N\end{array}$} & 0 & 7 & 7 & \\
\hline & $0 \%$ & $26.9 \%$ & $14.6 \%$ & \\
\hline \multirow{2}{*}{$\begin{array}{l}>2 \times U L N / \\
>2 \times G G N \\
\leq 3 \times U L N / \\
\leq 3 \times G G N\end{array}$} & 0 & 1 & I & 0.030 \\
\hline & $0 \%$ & $3.8 \%$ & $2.1 \%$ & \\
\hline \multirow{2}{*}{$\begin{array}{l}>3 \times \text { ULN/ } \\
>3 \times G G N \\
\leq 4 \times U L N / \\
\leq 4 \times G G N\end{array}$} & I & 0 & I & \\
\hline & $4.5 \%$ & $0 \%$ & $2.1 \%$ & \\
\hline \multirow[t]{2}{*}{ Total/Łącznie } & 22 & 26 & 48 & \\
\hline & $100.0 \%$ & $100.0 \%$ & $100.0 \%$ & \\
\hline
\end{tabular}

ULN - upper limit of normal.

GGN - górna granica normy.

tice as an alternative to KL-6 [30, 36-38]. An attempt to evaluate the utility of CA 15-3 in SSc-ILD has been made in various studies $[29,30,34]$.

Szekanecz et al. studied levels of selected tumorassociated antigens (CEA, CA 15-3, CA 72-4, CA 125, CA 19-9) in 92 patients with SSc, 40 patients with systemic lupus erythematosus, 50 patients in age- and sexmatched healthy controls and 40 patients with ongoing viral or bacterial infection. Levels of CA 19-9, CA 125, and CA 15-3 were significantly higher in patients with SSc than in healthy controls. What is more, a number of correlations between certain tumor-associated antigens and organ manifestations and laboratory parameters were found. CA 15-3, CEA and CA 19-9 directly correlated with renal involvement. Additionally, CA 15-3 correlated with joint involvement, presence of antinuclear antibodies and levels of C-reactive protein (CRP) [34]. In contrast, our study revealed correlations between levels of CA 15-3 and CA 125 and presence of SSc-ILD, which were not found by Szekanecz et al.

De Luca et al. assessed levels of selected tumor-associated antigens (CEA, CA 19-9, CA 15-3, CA 125, cytokeratin fragment antigen 21-1 - CYFRA 21-1, tissue polypeptide antigen - TPA, neuron-specific enolase - NSE) in 80 patients with SSc-ILD and in 40 patients with SSc without ILD (healthy controls) at baseline and after a 2-year follow-up during which progression of ILD was evaluat- nia. Stężenia rozpuszczalnych postaci markerów nowotworowych można oznaczyć w surowicy pacjentów, a w razie potrzeby powtórzyć pomiar [27, 28, 30, 34].

Rola markerów nowotworowych w chorobach o podłożu autoimmunologicznym nie jest do końca poznana. Niektóre z nich (CEA, CA 19-9, CA 125 i CA 15-3) mogą pełnić funkcję cząsteczek adhezyjnych dla komórek (CAM). Ich struktura molekularna obejmuje motywy węglowodanowe, które wiążą się z selektyną E, co wywołuje aktywację śródbłonka w toku procesów zapalnych leżących u podstaw wielu różnych stanów chorobowych, takich jak SSc [30, 34]. Wzrost stężeń cząsteczek pochodzenia płucnego w surowicy w przebiegu stanów zapalnych, m.in. stanowiących podłoże SSc, jest skutkiem różnych mechanizmów, takich jak zwiększone wytwarzanie w przebiegu zapalenia oraz zmniejszony rozpad i przepuszczalność bariery pęcherzykowo-włośniczkowej, powodujących nasilony wyciek do krążenia ogólnoustrojowego [27]. Marker CA 15-3 jest produktem tego samego genu, który odpowiada za wydzielanie KL-6, dlatego może być wykorzystywany w praktyce klinicznej jako alternatywa dla KL-6 [30, 3638]. Próby oceny przydatności oznaczenia CA 15-3 w SSc-ILD podejmowano w różnych badaniach [29, 30, 34].

Szekanecz i wsp. badali stężenia wybranych markerów nowotworowych (CEA, CA 15-3, CA 72-4, CA 125, CA 19-9) u 92 pacjentów z SSc, 40 pacjentów z toczniem rumieniowatym układowym, 50 zdrowych osób dobranych pod względem wieku i płci stanowiących grupę kontrolną oraz 40 pacjentów z zakażeniem wirusowym lub bakteryjnym. Stężenia CA 19-9, CA 125 i CA 15-3 były istotnie wyższe u pacjentów z SSc niż w grupie kontrolnej. Ponadto stwierdzono wiele zależności między niektórymi markerami nowotworowymi i objawami narządowymi oraz parametrami laboratoryjnymi. Stężenia CA 15-3, CEA i CA 19-9 wykazały korelację z zajęciem nerek. Ponadto potwierdzono związek między stężeniem CA 15-3 a zajęciem stawów, obecnością przeciwciał przeciwjądrowych i stężeniem białka C-reaktywnego (C-reactive protein - CRP) [34]. W przeciwieństwie do wyników przedstawionych w pracy Szekanecz i wsp. w naszym badaniu stwierdzono zależności pomiędzy stężeniem CA 15-3 i CA 125 a występowaniem SSc-ILD.

De Luca i wsp. oceniali stężenia wybranych markerów nowotworowych (CEA, CA 19-9, CA 15-3, CA 125, fragmentu cytokeratyny 21-1 - CYFRA 21-1, tkankowego markera polipeptydowego - TPA, swoistej enolazy neuronowej - NSE) u 80 pacjentów z SSc-ILD i 40 pacjentów z SSc bez ILD (grupa kontrolna) na początku badania i po dwuletnim okresie obserwacji. Progresje ILD analizowano u 80 pacjentów z SSc-ILD i 40 pacjentów z SSc bez ILD. Stężenia CA 15-3, CA 19-9 i CEA były wyższe u pacjentów z SSc-ILD. W analizie wyjściowej podwyższone stężenie co najmniej jednego markera nowotworowego powyżej górnej wartości granicznej było związane z uogólnioną postacią choroby i obecnością 
Table 3. CA I 5-3 levels in patients with systemic sclerosis with or without interstitial lung disease

Tabela 3. Stężenia CA I 5-3 u pacjentek z twardziną układową ze śródmiąższową chorobą płuc lub bez niej

\begin{tabular}{|c|c|c|c|c|}
\hline \multirow[t]{2}{*}{ CA $15-3$} & \multicolumn{2}{|c|}{ Interstitial lung disease/Śródmiąższowa choroba płuc } & \multirow[t]{2}{*}{ Total/Łącznie } & \multirow{2}{*}{$\begin{array}{l}\text { Value of } p / \\
\text { Wartośc } p\end{array}$} \\
\hline & Absent/Nieobecna & Present/Obecna & & \\
\hline \multirow{2}{*}{$\begin{array}{l}\text { Normal levels/ } \\
\text { Wartości prawidłowe }\end{array}$} & 22 & 17 & 39 & \\
\hline & $95.7 \%$ & $68.0 \%$ & $81.3 \%$ & \\
\hline \multirow{2}{*}{$\begin{array}{l}>1 \times U L N />1 \times G G N \\
\leq 2 \times U L N / \leq 2 \times G G N\end{array}$} & I & 6 & 7 & \\
\hline & $4.3 \%$ & $24.0 \%$ & $14.6 \%$ & 0.046 \\
\hline \multirow{2}{*}{$\begin{array}{l}>2 \times U L N />2 \times G G N \\
\leq 3 \times U L N / \leq 3 \times G G N\end{array}$} & 0 & 2 & 2 & \\
\hline & $0 \%$ & $8.0 \%$ & $4.2 \%$ & \\
\hline \multirow[t]{2}{*}{ Total/L̨ącznie } & 23 & 25 & 48 & \\
\hline & $100.0 \%$ & $100.0 \%$ & $100.0 \%$ & \\
\hline
\end{tabular}

ULN - upper limit of normal. GGN - górna granica normy.

ed in 80 patients with SSc-ILD and in 40 patients with SSc without ILD. Levels of CA 15-3, CA 19-9 and CEA were higher in the group of patients with SSc-ILD. At baseline analysis, elevation above the cut-off level of at least one tumor-associated antigens was associated with diffuse form of the disease and presence of anti-Scl70 antibodies. It also correlated with lower FVC values, higher interstitial and alveolar scores. Levels of CA 15-3 and CEA correlated inversely with FVC and directly with alveolar and interstitial scores. Of interest, patients with worsening of the interstitial score after 2 years of follow-up presented higher levels of CA 15-3 and CA 125 at baseline compared with patients with a stable interstitial score [30]. In our study, serum levels of CA 15-3 as well as levels of CA 125 were also higher among patients with SSc-ILD compared to the group of SSc patients without ILD. However, contrary to the previous study [30], levels of CA 19-9 and CEA did not correlate with presence of SSc-ILD.

Celeste et al. evaluated the utility of CA 15-3 in patients with SSc-ILD. Two hundred and twenty-one SSc patients were consecutively studied and CA 15-3 levels were determined. Similarly to our study, patients without ILD had lower CA 15-3 levels compared to patients with ILD. CA 15-3 levels in the sera of patients correlated directly with HRCT scores [29].

Utility of CA 125 in SSc has been noted by independent researchers apart from our study. Kimura et al. suggested that elevated serum levels of this tumorassociated antigen may serve as an indicator of pleural effusion in various collagen diseases [32]. Takeda et al. reported a patient with SSc/systemic lupus erythematosus overlap syndrome who presented with an elevated CA 125 level in pleural fluid [39]. Similarly, Funauchi et al. described a patient with pleural effusion in the course of SSc, in which levels of CA 125 both in the serum and pleural fluid were elevated [31]. The usefulness of CA 125 and CEA assessment in ILD was researched by Dai et al. CA 125 and CEA levels were significantly higher in patients with ILD compared to przeciwciał anty-Scl70. Korelowało również z niższymi wartościami FVC oraz większym nasileniem zmian w HRCT. Dla stężeń CA 15-3 i CEA wykazano odwrotną korelację z wartością FVC i zależność $\mathrm{z}$ wynikami oceny zaawansowania zmian w HRCT. U pacjentów z pogorszeniem wyniku oceny śródmiąższowej po 2 latach obserwacji stężenia CA 15-3 i CA 125 na początku badania były wyższe $\mathrm{w}$ porównaniu $\mathrm{z}$ pacjentami ze stabilnym wynikiem oceny śródmiąższowej [30]. W naszym badaniu stężenia CA 15-3 oraz CA 125 w surowicy także były wyższe u chorych z SSc-ILD niż u pacjentów z SSc bez ILD. Jednak w przeciwieństwie do poprzedniego badania [30] stężenia CA 19-9 i CEA nie korelowały z występowaniem SSc-ILD.

Przydatność oznaczenia CA 15-3 u pacjentów z SSc-ILD oceniali w swojej pracy Celeste i wsp. w grupie obejmującej 221 pacjentów z SSc, u których wykonano oznaczenie stężenia CA 15-3. Podobnie jak w naszym badaniu u pacjentów bez ILD stwierdzono niższe stężenie CA 15-3 w porównaniu z pacjentami z ILD. Stężenia CA 15-3 w surowicy pacjentów korelowały bezpośrednio z zaawansowaniem zmian w obrębie miąższu płucnego ocenianych na podstawie badania HRCT [29].

Przydatność oznaczenia CA 125 u pacjentów z SSc opisywali także inni badacze. Kimura i wsp. zasugerowali, że podwyższone stężenie tego markera nowotworowego w surowicy może służyć jako wskaźnik występowania wysięku opłucnowego w przebiegu różnych kolagenoz [32]. Takeda i wsp. opisali przypadek pacjenta $\mathrm{z}$ zespołem nakładania SSc i tocznia rumieniowatego układowego, u którego stwierdzono podwyższone stężenie CA 125 w płynie opłucnowym [39]. Podobnie Funauchi i wsp. przedstawili przypadek pacjentki z wysiękiem opłucnowym w przebiegu SSc, u której stężenie CA 125 było podwyższone zarówno w surowicy, jak i płynie opłucnowym [31]. Przydatność oceny CA 125 i CEA w ILD badali Dai i wsp., stwierdzając istotnie podwyższone stężenia CA 125 i CEA u pacjentów z ILD w porównaniu ze zdrowymi osobami z grupy 
healthy controls. Moreover, an increased risk of developing lung cancer was observed with an elevation of certain tumor-associated antigens' serum levels [40]. In our study presence of lung cancer was excluded in all patients among those with elevated tumor-associated antigens. The limitations of our research are its retrospective character and the small size of the patient population.

\section{CONCLUSIONS}

Elevated serum levels of selected tumor-associated antigens are observed among patients with SSc. Some of them are in direct correlation with pulmonary involvement. Therefore, regular assessment of selected tumor-associated antigens in sera of SSc patients seems to be vital in early diagnosis of SSc-ILD and provides required therapy in order to prevent disease progression and development of serious, even lifethreating complications. Future research concerning the role of tumor-associated antigens in SSc and their associations with organ involvement is necessary.

\section{CONFLICT OF INTEREST}

The authors declare no conflict of interest. kontrolnej. Ponadto obserwowano zwiększone ryzyko zachorowania na raka płuca przy podwyższonych stężeniach określonych markerów nowotworowych w surowicy [40]. W naszym badaniu wykluczono obecność raka płuca u wszystkich pacjentek z podwyższonym stężeniem markerów nowotworowych. Wśród ograniczeń badania należy wskazać jego retrospektywny charakter oraz niewielką liczebność badanej populacji pacjentek.

\section{WNIOSKI}

U pacjentów z SSc stwierdza się podwyższone stężenia pewnych markerów nowotworowych. Niektóre z nich wykazują bezpośrednią korelację z zajęciem płuc. Regularne oznaczanie wybranych markerów nowotworowych w surowicy pacjentów z SSc może mieć kluczowe znaczenie we wczesnej diagnostyce SSc-ILD i umożliwia wdrożenie odpowiedniego leczenia, a także zapobiega progresji choroby i wystąpieniu poważnych, a nawet zagrażających życiu powikłań. Niezbędne są dalsze badania dotyczące roli markerów nowotworowych w SSc i ich związku z zajęciem narządów.

\section{KONFLIKT INTERESÓW}

Autorzy nie zgłaszają konfliktu interesów.

\section{References \\ Piśmiennictwo}

1. Stern E.P., Denton C.P.: The pathogenesis of systemic sclerosis. Rheum Dis Clin North Am 2015, 41, 367-382.

2. Viswanath V., Phiske M.M., Gopalani V.V: Systemic sclerosis: current concepts in pathogenesis and therapeutic aspects of dermatological manifestations. Indian J Dermatol 2013, 58, 255-268.

3. Stochmal A., Czuwara J., Trojanowska M., Rudnicka L.: Antinuclear antibodies in systemic sclerosis: an update. Clin Rev Allergy Immunol 2020, 58, 40-51.

4. Al-Sheikh H., Ahmad Z., Johnson S.R.: Ethnic variations in systemic sclerosis disease manifestations, internal organ involvement, and mortality. J Rheumatol 2019, 46, 1103-1108.

5. Cappelli S., Bellando Randone S., Camiciottoli G., De Paulis A., Guiducci S., Matucci-Cerinic M.: Interstitial lung disease in systemic sclerosis: where do we stand? Eur Respir Rev 2015, 24, 411-419.

6. Giacomelli R., Liakouli V., Berardicurti O., Ruscitti P., Di Benedetto P., Carubbi F., et al.: Interstitial lung disease in systemic sclerosis: current and future treatment. Rheumatol Int 2017, 37, 853-863.

7. Krasowska D., Rudnicka L., Dańczak-Pazdrowska A., Chodorowska G., Woźniacka A., Lis-Święty A., et al.: Systemic sclerosis diagnostic and therapeutic recommendations of the Polish Dermatological Society. Part 1: diagnosis and monitoring. Dermatol Rev 2017, 104, 483-498.

8. Chowaniec M., Skoczyńska M., Sokolik R., Wiland P.: Interstitial lung disease in systemic sclerosis: challenges in early diagnosis and management. Reumatologia 2018, 56, 249-254.

9. Cottin V., Brown K.K.: Interstitial lung disease associated with systemic sclerosis (SSc-ILD). Respir Res 2019, $20,13$.

10. Rubio-Rivas M., Royo C., Simeón C.P., Corbella X., Fonollosa V.: Mortality and survival in systemic sclerosis: systematic review and meta-analysis. Semin Arthritis Rheum 2014, 44, 208-219.

11. Benyamine A., Heim X., Resseguier N., Bertin D., Gomez C., Ebbo M., et al.: Elevated serum Krebs von den Lungen-6 in systemic sclerosis: a marker of lung fibrosis and severity of the disease. Rheumatol Int 2018, 38, 813-819.

12. Bonella F., Volpe A., Caramaschi P., Nava C., Ferrari P., Schenk K., et al.: Surfactant protein D and KL-6 serum levels in systemic sclerosis: correlation with lung and systemic involvement. Sarcoidosis Vasc Diffuse Lung Dis 2011, 28, 27-33.

13. Cao X.Y., Hu S.S., Xu D., Li M.T., Wang Q., Hou Y., et al.: Serum levels of Krebs von den Lungen-6 as a promising marker for predicting occurrence and deterioration of systemic sclerosis-associated interstitial lung disease from a Chinese cohort. Int J Rheum Dis 2019 , 22, 108-115.

14. Elhai M., Hoffmann-Vold A.M., Avouac J., Pezet S., Cauvet A., Leblond A., et al.: Performance of candidate serum biomarkers for systemic sclerosis-interstitial lung disease. Arthritis Rheumatol 2019, 71, 972-982. 
15. Hant F.N., Ludwicka-Bradley A., Wang H.J., Li N., Elashoff R., Tashkin D.P., et al.: Surfactant protein D and KL-6 as serum biomarkers of interstitial lung disease in patients with scleroderma. J Rheumatol 2009, 36, 773-780.

16. Hesselstrand R., Wildt M., Bozovic G., Andersson-Sjöland A., Andréasson K., Scheja A., et al.: Biomarkers from bronchoalveolar lavage fluid in systemic sclerosis patients with interstitial lung disease relate to severity of lung fibrosis. Respir Med 2013, 107, $1079-1086$.

17. Kennedy B., Branagan P., Moloney F., Haroon M., O'Connell O.J., O'Connor T.M., et al.: Biomarkers to identify ILD and predict lung function decline in scleroderma lung disease or idiopathic pulmonary fibrosis. Sarcoidosis Vasc Diffuse Lung Dis 2015, 32, 228-236.

18. Kumánovics G., Görbe E., Minier T., Simon D., Berki T., Czirják L.: Follow-up of serum KL-6 lung fibrosis biomarker levels in 173 patients with systemic sclerosis. Clin Exp Rheumatol 2014, 32, 138-144.

19. Kumánovics G., Minier T., Radics J., Pálinkás L., Berki T., Czirják L.: Comprehensive investigation of novel serum markers of pulmonary fibrosis associated with systemic sclerosis and dermato/polymyositis. Clin Exp Rheumatol 2008, 26, 414-420.

20. Kuwana M., Shirai Y., Takeuchi T.: Elevated serum Krebs von den Lungen-6 in early disease predicts subsequent deterioration of pulmonary function in patients with systemic sclerosis and interstitial lung disease. J Rheumatol 2016, 43, 1825-1831.

21. Salazar G.A., Kuwana M., Wu M., Estrada-Y-Martin R.M., Ying J., Charles J., et al.: KL-6 but not CCL-18 is a predictor of early progression in systemic sclerosis-related interstitial lung disease. J Rheumatol 2018, 45, 1153-1158.

22. Sato S., Nagaoka T., Hasegawa M., Nishijima C., Takehara K.: Elevated serum KL-6 levels in patients with systemic sclerosis: association with the severity of pulmonary fibrosis. Dermatology 2000, 200, 196-201.

23. Yamakawa H., Hagiwara E., Kitamura H., Yamanaka Y., Ikeda S., Sekine A., et al.: Serum KL-6 and surfactant protein-D as monitoring and predictive markers of interstitial lung disease in patients with systemic sclerosis and mixed connective tissue disease. $J$ Thorac Dis 2017, 9, 362-371.

24. Yamane K., Ihn H., Kubo M., Yazawa N., Kikuchi K., Soma Y., et al.: Serum levels of KL-6 as a useful marker for evaluating pulmonary fibrosis in patients with systemic sclerosis. J Rheumatol 2000, 27, 930-934.

25. Yanaba K., Hasegawa M., Hamaguchi Y., Fujimoto M., Takehara K., Sato S.: Longitudinal analysis of serum KL-6 levels in patients with systemic sclerosis: association with the activity of pulmonary fibrosis. Clin Exp Rheumatol 2003, 21, 429-436.

26. Yanaba K., Hasegawa M., Takehara K., Sato S.: Comparative study of serum surfactant protein-D and KL-6 concentrations in patients with systemic sclerosis as markers for monitoring the activity of pulmonary fibrosis. J Rheumatol 2004, 31, 1112-1120.

27. Bonella F., Costabel U.: Biomarkers in connective tissue disease-associated interstitial lung disease. Semin Respir Crit Care Med 2014, 35, 181-200.

28. Lota H.K., Renzoni E.A.: Circulating biomarkers of interstitial lung disease in systemic sclerosis. Int J Rheumatol 2012, $2012,121439$.

29. Celeste S., Santaniello A., Caronni M., Franchi J., Severino A., Scorza R., et al.: Carbohydrate antigen 15.3 as a serum biomarker of interstitial lung disease in systemic sclerosis patients. Eur J Intern Med 2013, 24, 671-676.

30. De Luca G., Bosello S.L., Berardi G., Rucco M., Canestrari G., Correra M., et al.: Tumour-associated antigens in systemic sclerosis patients with interstitial lung disease: association with lung involvement and cancer risk. Rheumatology (Oxford) 2015, 54, $1991-1999$.

31. Funauchi M., Ikoma S., Yu H., Sugiyama M., Ohno M., Kinoshita K., et al.: A case of progressive systemic sclerosis complicated by massive pleural effusion with elevated CA125. Lupus 2000, 9, 382-385.

32. Kimura K., Ezoe K., Yokozeki H., Katayama I., Nishioka K.: Elevated serum CA125 in progressive systemic sclerosis with pleural effusion. J Dermatol 1995, 22, 28-31.

33. Shimomura C., Eguchi K., Kawakami A., Migita K., Nakao H., Otsubo T., et al.: Elevation of a tumor associated antigen CA 19-9 levels in patients with rheumatic diseases. J Rheumatol 1989, 16, 1410-1415.

34. Szekanecz E., Szucs G., Szekanecz Z., Tarr T., Antal-Szalmás P., Szamosi S., et al.: Tumor-associated antigens in systemic sclerosis and systemic lupus erythematosus: associations with organ manifestations, immunolaboratory markers and disease activity indices. J Autoimmun 2008, 31, 372-376.

35. Valerio Marzano A., Morabito A., Berti E., Caputo R.: Elevated circulating CA 15.3 levels in a subset of systemic sclerosis with severe lung involvement. Arch Dermatol 1998, 134, 645.

36. Sharma S.: Tumor markers in clinical practice: general principles and guidelines. Indian J Med Paediatr Oncol 2009, 30, 1-8

37. Willemsen A.E., Grutters J.C., Gerritsen W.R., Tol J., van Herpen C.M.: Caution for interstitial lung disease as a cause of CA 15-3 rise in advanced breast cancer patients treated with everolimus. Int J Cancer 2014, 135, 1007.

38. Kruit A., Gerritsen W.B., Pot N., Grutters J.C., van den Bosch J.M., Ruven H.J.: CA 15-3 as an alternative marker for KL-6 in fibrotic lung diseases. Sarcoidosis Vasc Diffuse Lung Dis 2010, 27, 138-146.

39. Takeda N., Ihn H., Teramoto S.: Markedly increased levels of IL-6 and CA125 in pleural fluid of an elderly person with overlap syndrome of systemic sclerosis and systemic lupus erythematosus. Age Ageing 2001, 30, 171.

40. Dai H., Liu J., Liang L., Ban C., Jiang J., Liu Y., et al.: Increased lung cancer risk in patients with interstitial lung disease and elevated CEA and CA125 serum tumour markers. Respirology 2014, 19, 707-713.

Received: 9.10.2019

Accepted: 24.07.2020

Otrzymano: 9.10.2019 r.

Zaakceptowano: $24.07 .2020 \mathrm{r}$.

How to cite this article

Fijołek F., Pasierb B., Gerkowicz A., Krasowska D.: Utility of selected tumor-associated antigens in systemic sclerosis-related interstitial lung disease - a retrospective single-center study. Dermatol Rev/Przegl Dermatol 2020, 107, 323-331.

DOI: https://doi.org/10.5114/dr.2020.99877. 